\title{
Pengaruh Attachment dan Penyesuaian Diri terhadap Self-Esteem Siswa SMP Teuku Umar Semarang Tahun Pelajaran 2019/2020
}

\author{
Erina Vicky Alfina ${ }^{1}$, Awalya $^{2}$ \\ 1,2 Universitas Negeri Semarang
}

*Corresponding author, e-mail: erinavicky.bat@gmail.com

\begin{abstract}
This study aims to determine the effect of attachment and self-adjustment on the self-esteem of Teuku Umar Junior High School students in Semarang Academic Year 2019/2020. Efforts to achieve goals, researchers use this type of quantitative research with ex post facto research designs. In practice, researchers used simple random sampling. Collecting data by spreading attachment scale, adjustment and self-esteem. The validity test used the product moment formula and the reliability test used Cronbach's alpha. The data analysis technique used multiple regression analysis test. The research that has been done has resulted in the level of self-esteem and attachment in the high category. Meanwhile, the level of adjustment is in the medium category. The results of the first hypothesis analysis show that there is a positive and significant effect of attachment on self-esteem. The results of the second hypothesis analysis indicate that there is a positive and significant effect of self-adjustment on self-esteem. The results of the analysis of the third hypothesis can be seen that there is a significant effect of attachment and selfadjustment on self-esteem. The results of this study concluded that the higher the attachment and self-adjustment, the higher the self-esteem of students. The research suggestion from these findings is that guidance and counseling teachers should provide several services that are related to attachment, adjustment and self-esteem by paying attention to student needs. This step is used so that students have more positive attachments, good adjustment in the hope that students have better self-esteem as well.
\end{abstract}

Keyword: Attachment, adjustment, self-esteem.

\section{Pendahuluan}

Dewasa ini di era milenial dimana perkembangan zaman sangat pesat kemajuannya dan dengan perkembangan yang sedemikian rupa membuat semua orang secara umumnya, dan remaja pada khususnya mau tidak mau mengikuti perkembangan tersebut. Tidak hanya dari segi teknologi tapi dari sikap dan perilakunya yang dapat dilihat dan dinilai oleh siapa saja yang melihatnya. Selain penilaian orang lain, seseorang juga bisa menilai dirinya sendiri dan seseorang yang dapat menilai dirinya dengan baik berarti memiliki self-esteem yang baik. Self-esteem dapat dikatakan sebagai evaluasi seseorang dalam menilai diri sendiri, dimana menilai kepuasan seseorang terhadap diri sendiri (Febrina, Suharso, \& Saleh, 2018). Dengan kata lain, self-esteem juga dapat diartikan sebagai bagaimana perasaan individu dalam menilai diri sendiri yang kaitannya dengan prestasi, memiliki hubungan interpersonal yang baik, dan keadaan psikologis yang baik juga (Refnadi, 2018). Salah satu unsur yang perlu diperhatikan terutama dalam membentuk konsep diri individu adalah selfesteem, karena self-esteem tersebut akan berpengaruh terhadap sikap dan perilaku dari individu itu sendiri (Srisayekti \& Setiady, 2015).

Self-esteem adalah salah satu bagian yang penting untuk membentuk pribadi seseorang. Dimana ketika seseorang sukar menghargai diri sendiri maka tidak menutup kemungkinan jika 
seseorang tersebut juga sukar untuk menghargai orang lain (Srisayekti \& Setiady, 2015). Kondisi dari self-esteem seseorang akan membawa pengaruh yang cukup besar, sebab self-esteem yang tinggi akan menunjang siswa untuk berprestasi dibidang akademik, namun begitu juga dengan selfesteem yang rendah tidak menjamin seseorang dapat berprestasi dibidang akademik (Refnadi, 2018). Oleh karena itu self-esteem yang tinggi memang diperlukan untuk menunjang kehidupan yang lebih baik lagi, selain itu dengan memiliki self-esteem yang tinggi juga akan membuat seseorang menjadi lebih bijaksana dalam menyikapi keadaan yang terjadi dikehidupan. Sehingga dengan demikian akan membuat hidup lebih bermanfaat bukan hanya untuk diri sendiri namun juga bermanfaat untuk orang lain.

Mutu pendidikan Indonesia periode 2013 dan 2014 yang dipetakan oleh The Learning Curve - Pearson, Indonesia berada diposisi paling bawah dari 40 negara, sedangkan oleh UNESCO pada tahun 2014 terdapat 0,001\% kesadaran diri membaca pada orang Indonesia atau dapat dikatakan hanya ada 1 dari 1000 orang yang sadar bahwa membaca itu penting. Hal yang sudah sering terjadi ketika hendak meraih prestasi maka banyak cara yang akan ditempuh baik itu cara yang baik maupun cara yang tidak baik seperti mencontek dan beberapa terjadi perjokian dikalangan pelajar (Refnadi, 2018). Dari hal tersebut meluas hingga minat siswa terhadap pendidikan kurang dan keinginan untuk berprestasipun sangat minim (Refnadi, 2018). Oleh karena itu, untuk meminimalisir permasalahan tersebut siswa perlu memiliki self-esteem yang tinggi. Apabila selfesteem siswa tinggi maka siswa akan menjadi lebih berharga, lebih melihat bahwa dirinya perlu dihormati oleh dirinya sendiri, selain itu juga melihat bahwa dirinya sama tingginya dengan orang lain sehingga membuat dirinya menjadi lebih percaya diri. Percaya diri yang sudah terbentuk tersebut akan membuat siswa menjadi berpikir lebih kreatif untuk menciptakan hal-hal baru dan semua itu akan membawa dirinya menjadi berkembang mengikuti perkembngan zaman. Berkebalikan dengan siswa yang memiliki self-esteem yang rendah, diantaranya akan merasakan bahwa dirinya tidak berharga sehingga ketika akan melakukan apapun tidak percaya diri, dan hal tersebut berasal dari pengaruh negatif yang didapatkan dari lingkungan dimana siswa tersebut tinggal dan berdomisili karena dari lingkungan tersebut juga mempengaruhi psikologisnya. Kecenderungan dari siswa yang memiliki self-esteem yang rendah adalah kebingungan dalam mencari jati diri, status dalam bermasyarakat, sukar mendapat pengakuan dari banyak pihak dan seringkali karena kebingungan tersebut membuat perilaku dari siswa yang memiliki self-esteem rendah itu akan menyimpang dari norma yang berlaku dimasyarakat (Refnadi, 2018).

Berdasarkan hasil studi pendahuluan peneliti yang dilakukan di SMP Teuku Umar Semarang pada tanggal 17 Februari 2020 dan tanggal 5 Maret 2020 melakukan wawancara dengan salah satu guru bimbingan dan konseling dan beberapa wali kelas di SMP Teuku Umar Semarang Tahun Pelajaran 2019/2020, dimana wawancara yang dilakukan oleh peneliti lebih mengarah pada selfesteem siswa di sekolah. Menurut guru BK dan Wali kelas, siswa memiliki self-esteem yang cukup rendah sebab karena menurut wawancara yang sudah dilakukan, wali kelas dan guru bimbingan dan konseling beberapa kali masih melihat perilaku siswa kelas VII, VIII yang masih kurang menghargai guru ketika guru sedang menjelaskan di kelas, terkadang ketika sedang belajar di kelas ada yang makan, dalam berkomunikasi sudah lumayan baik dalam arti menggunakan bahasa jawa namun terkadang penggunaan bahasanya masih kurang tersusun dengan baik dan kadang siswa 
menggampangkan lawan bicaranya. Wali kelas juga mengeluhkan ketika ada guru yang masuk ke kelas, siswa ramai sekali dan hanya akan mau mendengarkan dengan baik guru-guru tertentu saja.

Dari sekian banyaknya fenomena yang terjadi tersebut dapat dikatakan bahwa hal tersebut cerminan dari self-esteem pada diri siswa yang rendah sesuai dengan komponen self-esteem tepatnya dalam general self-esteem yang memiliki landasan dimana perasaan dan self-worth tidak sesuai atau berseberangan dengan self-esteem. Sehingga membawa pengaruh terhadap arah dan hal apa saja yang akan dilakukan dalam waktu dekat akan menjadi tolak ukur dalam berperilaku seharihari. Self-esteem adalah salah satu bagian yang penting untuk membentuk pribadi seseorang. Dimana ketika seseorang sukar menghargai diri sendiri maka tidak menutup kemungkinan jika seseorang tersebut juga sukar untuk menghargai orang lain (Srisayekti \& Setiady, 2015). Kondisi dari self-esteem seseorang akan membawa pengaruh yang cukup besar, sebab self-esteem yang tinggi akan menunjang siswa untuk berprestasi dibidang akademik, namun begitu juga dengan selfesteem yang rendah tidak menjamin seseorang dapat berprestasi dibidang akademik (Refnadi, 2018). Oleh karena itu self-esteem yang tinggi memang diperlukan untuk menunjang kehidupan yang lebih baik lagi, selain itu dengan memiliki self-esteem yang tinggi juga akan membuat seseorang menjadi lebih bijaksana dalam menyikapi keadaan yang terjadi dikehidupan.

Self-esteem akan terus berkembang dengan berbagai hal penunjang yang mempengaruhinya dan terbagi menjadi beberapa faktor, salah satunya adalah faktor keluarga. Faktor keluarga ini mencakup hubungan kelekatan anak dengan orang tua, pola asuh orang tua, selain itu juga terdapat faktor identitas yang didalamnya terdapat peran gender dan identitas etnis. Faktor lain yaitu faktor kompetensi diri dimana terdapat prestasi akademik dan prestasi non akademik. Dari berbagai faktor tersebut, penulis akan mengupas mengenai hubungan kelekatan anak dengan orang tua atau sering disebut sebagai attachment. Attachment adalah suatu ikatan yang sangat penting karena dengan ikatan ini menjadi titik tumpu berhasil tidaknya seorang anak dapat beradaptasi dan berorientasi dengan masyarakat dalam lingkungan yang baru. Oleh karena itu peneliti melakukan penelitian ini karena akan menggunakan attachment sebagai dasar seseorang untuk berkembang dari cakupan yang kecil (keluarga) menuju lingkungan dengan cakupan yang lebih luas.

Beberapa ahli memberikan pedapat mengenai attachment, salah satunya menurut Monks (dalam Cenceng, 2015) attachment merupakan usaha seseorang dalam menjaga kontak namun dengan orang tertentu misalnya ibu, bapak, atau saudara dekat dari seseorang yang dianggap berpengaruh dalam dirinya. Pendapat tersebut didukung juga oleh Santrock (dalam Putri \& Wangid, 2017) yang mengatakan bahwa attachment merupakan emosional antara dua orang yang tergabung dalam satu ikatan. Ahli selanjutnya Ainsworth (dalam Cenceng, 2015) juga menyampaikan pendapatnya tentang attachment merupakan suatu emosional bersifat spesifik lalu diikat oleh seorang individu karena pada sebuah hubungan biasanya dilengkapi dengan tingkah,laku/lekat (attachment behavior) guna menjaga jalinan itu (Cenceng, 2015). Attachment (kelekatan) baru-baru ini antara orang tua dan anak terlihat berkurang. Berdasarkan data yang didapakan dari KPAI per 24 Oktober bahwa pada 2015 ada 255 korban dari pelanggaran jalur dimana anak tidak bisa bertemu dengan orang tuanya. Hal tersebut sebagian besar berlatar belakang dari keluarga broken home. Hal tersebut berlawanan dengan pernyataan yang menyatakan keperluan dari attachment pada orang tua merupakan bagian penting pada hidup seseorang terutama pada remaja (Puteri \& Wangid, 2018). Seorang anak yang mempunyai attachment kuat dengan orang tua itu menandakan bahwa proses awal tumbuh kembang anak dalam bersosialisasi dengan lingkungan sekitar menjadi baik. 
Karena dengan kemampuan bersosialisasi, seseorang akan memperoleh pengalaman sosial dari lingkungan yang lebih luas akan menjadikan motivasi agar dapat menyesuaikan diri dengan lingkungan sekitar.

Menurut Cole (dalam Imani Khan, 2012) mengatakan bahwa ketika terjadi perbedaan terhadap seseorang yang mengarah pada perubahan menjadi sosok seseorang yang lebih mandiri maka akan menyebabkan seseorang dapat menyesuaikan diri dengan hal yang cukup banyak. Misalnya emosi, mental dan sosial yang matang dan masih banyak lagi. Berangkat dari hal tersebut mengakibatkan permasalahan untuk seseorang dan mau tidak mau permasalahan tersebut hendaknya diatasi. Karena ketika permasalahan tersebut dibiarkan cenderung akan membuat seseorang menjadi mudah kecewa dengan keadaan, kurang menghargai dirinya sendiri dan bisa juga seseorang memandang bahwa dirinya sukar untuk berhasil. Seringkali seseorang mengupayakan dapat menyesuaikan diri dengan baik agar diterima oleh kelompok meskipun banyak hal yang dilakukannya itu bersifat negatif (Husni \& Purwaningsih, 2017). Maka dari itu penyesuaian diri diimplementasikan terkadang menggunakan tahap yang tidak mudah sebab perlu adanya pembiasaan agar dapat memberikan feedback pada satu keperluan tapi hal tersebut berlawanan dengan syarat lain. Berdasarkan penelitian yang sudah pernah dilakukan oleh peneliti sebelumnya menunjukkan bahwa penyesuaian diri memiliki hubungan dengan self-esteem siswa. Penelitian tersebut dilakukan oleh Margarethabertiutami (2016) yang mengatakan bahwa terdapat hubungan dan signifikan antara penyesuaian diri dengan self-esteem sebesar 0,754 menggunakan taraf signifikan 0,000 .

Untuk mengembangkan potensi yang dimiliki oleh siswa seringkali tidak mulus. Hambatan yang terjadi ini biasanya diluar kendali konselor sekolah ataupun pihak lain. Sebab dalam penanganannya, konselor sekolah hendaknya paham dari satu persatu problematika yang terjadi pada siswa dengan memperhatikan faktor-faktor yang melatar belakanginya. Karena dengan latar belakang tersebut membuat konselor sekolah dapat memahami lebih dalam permasalahan yang dialami oleh siswa dengan melihat dari berbagai sisi tidak hanya dari satu sisi saja. Begitu juga dalam upaya konselor sekolah dalam meningkatkan self-esteem siswa, karena self-esteem itu sangat penting bagi setiap siswa maka dari itu penting untuk konselor sekolah mengetahui apa saja yang mempengaruhi atau yang mendukung agar self-esteem pada siswa agar terus naik dan stabil. Dari penjelasan tersebut peneliti tertarik untuk melakukan penelitian dengan judul "Pengaruh Attachment dan Penyesuaian Diri Terhadap Self-esteem Siswa SMP Teuku Umar Semarang Tahun Pelajaran 2019/2020"..

\section{Metode}

Dalam penelitian ini peneliti menggunakan penelitian kuantitatif. Peneliti menggunakan penelitian kuantitatif karena peneliti memiliki maksud untuk menguji hipotesis penelitian. Hal tersebut didukung oleh pendapaat Sugiyono (2017) yang menjelaskan bahwa penelitian kuantitatif digunakan oleh peneliti ketika akan menguji hipotesis dalam penelitiannya yang meliputi hipotesis deskriptif, komparatif dan asosiatif.

Populasi penelitian ini adalah siswa Siswa SMP Teuku Umar Semarang yang bisa dilihat pada tabel berikut ini: 
Tabel 1. Rekapitulasi Populasi Siswa SMP Teuku Umar Semarang

\begin{tabular}{ccc}
\hline No & Kelas & Jumlah \\
\hline 1. & VII & 185 \\
2. & VIII & 198 \\
& Jumlah & 383 \\
\hline
\end{tabular}

Sampel yang diambil dari penelitian ini menggunakan teknik simple random sampling karena peneliti dalam pengambilan anggota sampelnya dilakukan secara acak dan tidak memperhatikan strata yang ada dalam populasi (Sugiyono, 2017). Pengambilan jumlah sampel ini menggunakan,tabel yang dikembangkan oleh Isaac dan Michael dengan tingkat kesalahan yang digunakan 5\% dari total populasi 383 siswa maka sampel yang digunakan berjumlah 182 siswa (Sugiyono, 2016: 71). Banyaknya siswa yang akan menjadi sampel diambil dari tiga kelas 7 dan tiga kelas 8 sehingga apabila ditotal menjadi enam kelas.

Tabel 2. Sampel Siswa Taraf Kesalahan 5\%

\begin{tabular}{cccc}
\hline No & Kelas & Populasi & Jumlah Sampel \\
\hline 1. & VII & 185 & 94 \\
2. & VIII & 198 & 88 \\
& Jumlah & 383 & 182 \\
\hline
\end{tabular}

Alat pengumpulan data yang digunakan oleh ketiga variabel menggunakan skala self-esteem untuk mendapatkan data self-esteem, menggunakan skala attachment untuk mendapatkan data attachment dan menggunakan skala penyesuaian diri untuk memperoleh data penyesuaian diri. Dalam penelitian ini menggunakan teknik analisis regresi linear sederhana dan menggunakan teknik analisis regresi ganda.

\section{Hasil dan Diskusi}

Berdasarkan data yang sudah ditemukan, diperoleh hasil analisis deskriptif tingkat attachment, penyesuaian diri dan self-esteem siswa sebagai berikut:

Tabel 3. Hasil Analisis Deskriptif Tingkat Attachment, Penyesuaian Diri dan Self-Esteem Siswa

\begin{tabular}{lcccc}
\hline \multicolumn{1}{c}{ Variabel } & N & M & SD & Kategori \\
\hline Self-Esteem & 182 & 100 & 20 & Tinggi \\
Attachment & 182 & 76 & 13,83 & Tinggi \\
Penyesuaian Diri & 182 & 54 & 12 & Sedang \\
\hline
\end{tabular}

Dari tabel 3 telah memberikan gambaran bahwa instrumen yang sudah dibagikan kepada 182 responden telah memberikan hasil diantaranya adalah variabel Self-Esteem $(\mathrm{M}=100, \mathrm{SD}=20)$ merupakan kategori yang tinggi, lain lagi dengan variabel attachment $(\mathrm{M}=76, \mathrm{SD}=13,83)$ yang memiliki kategori tinggi dan selanjutnya variabel penyesuaian diri $(M=54, S D=12)$ berdasarkan tabel 3 termasuk kategori sedang. Untuk lebih lengkapnya akan dijelaskan untuk masing-masing variabel, diantaranya adalah: 
Tabel 4. Distribusi Responden Tingkat Self-Esteem

\begin{tabular}{rcccc}
\hline No & Interval & Kategori & F & Persentase \\
\hline 1. & $\mathrm{X} \geq 120$ & Sangat Tinggi & 62 & $34,06 \%$ \\
2. & $100 \leq \mathrm{X}<120$ & Tinggi & 103 & $56,60 \%$ \\
3. & $80 \leq \mathrm{X}<100$ & Sedang & 16 & $8,80 \%$ \\
4. & $60 \leq \mathrm{X}<80$ & Rendah & 1 & $0,55 \%$ \\
5. & $\mathrm{X}<60$ & Sangat Rendah & 0 & $0,00 \%$ \\
\hline
\end{tabular}

Menurut tabel 4. dapat dikatakan bahwa,tingkat self-esteem siswa SMP Teuku Umar Semarang Tahun Pelajaran 2019/2020 dengan frekuensi paling tinggi adalah 103 siswa yang memiliki persentase 56,60\% dan termasuk ke dalam kategori tinggi. Kemudian frekuensi tinggi kedua adalah 62 siswa yang memiliki persentase $34,06 \%$ termasuk pada kategori sangat tinggi. Selanjutnya terdapat frekuensi sebanyakl18 siswa yang memiliki persentase 8,80\% dan termasuk pada kategori sedang. Dan ada 1 siswa yang berada dikategori rendah dengan persentase 0,55\%. Untuk lebih mudahnya, hasil dari penelitian ini ketika dilihat melalui grafik sebagai berikut:

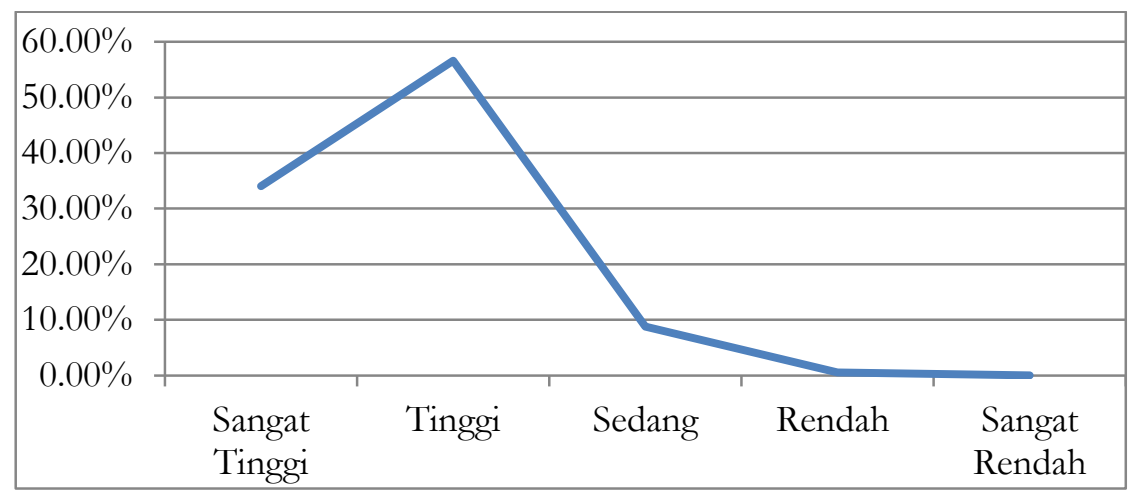

Gambar 1. Grafik Tingkat Self-Esteem

Berdasarkan gambar 1 dapat menunjukkan bahwa kecenderungan siswa SMP Teuku Umar Semarang Tahun pelajaran 2019/2020 mempunyai tingkat self-esteem yang tinggi dengan frekuensi 103 responden dan memiliki persentase 56,60\%. Selanjutnya deskripsi data dari setiap indikator pada variabel self-esteem adalah Kekuatan (Power), Kebajikan (Virtue), Kompetensi (Competence), Keberartian (Significance) dirangkum dalam tabel di bawah ini:

Tabe1 5. Hasil Analisis Deskriptif per Indikator Self-Esteem

\begin{tabular}{lccc}
\hline \multicolumn{1}{c}{ Indikator } & N & M & SD \\
\hline Kekuatan (Power) & 182 & 3,92 & 0,949 \\
Kebajikan (Virtue) & 182 & 3,82 & 0,916 \\
Kompetensi (Competence) & 182 & 3,88 & 1,03 \\
Keberartian (Significance) & 182 & 3,83 & 1,04 \\
\hline
\end{tabular}

Dari tabel 5 menunjukkan hasil analisis deskriptif (perindikator yang pertama indikator Kekuatan (Power) memiliki ( $\mathrm{M}=3,92 ; \mathrm{SD}=0,949)$, kompetensi (competence) sebanyak ( $\mathrm{M}=3,88 ; \mathrm{SD}$ $=1,03)$, kebajikan (virtue) memiliki $(\mathrm{M}=3,82$; $\mathrm{SD}=0,916)$, dan yang terakhir yaitu keberartian (significance) sebanyak $(\mathrm{M}=3,83 ; \mathrm{SD}=1,04)$. Untuk lebih jelasnya dapat dilihat pada grafik di bawah ini: 


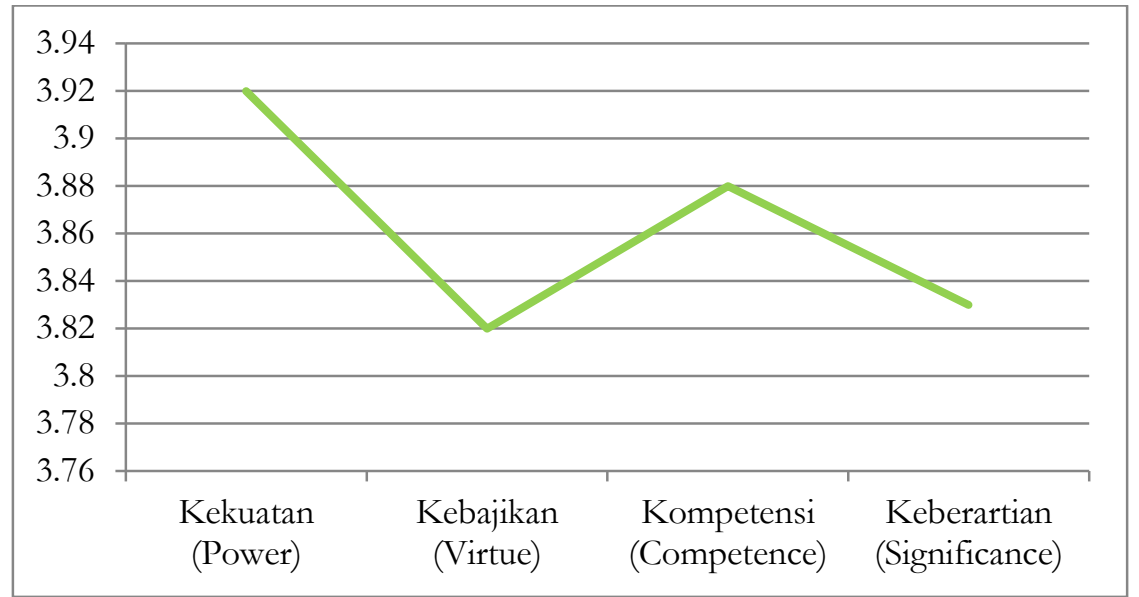

Gambar 2. Grafik Tingkat Self-Esteem per Indikator

Selanjutnya diperoleh data dari attachment yang tertera pada tabel berikut:

Tabel 6. Distribusi Responden Tingkat Attachment

\begin{tabular}{ccccc}
\hline No & Interval & Kategori & F & Persentase \\
\hline 1. & $\mathrm{X} \geq 86,75$ & Sangat Tinggi & 82 & $45,06 \%$ \\
2. & $72,92 \leq \mathrm{X}<86,75$ & Tinggi & 86 & $47,25 \%$ \\
3. & $59,08 \leq \mathrm{X}<72,92$ & Sedang & 13 & $7,14 \%$ \\
4. & $45,25 \leq \mathrm{X}<59,08$ & Rendah & 1 & $0,55 \%$ \\
5. & $\mathrm{X}<45,25$ & Sangat Rendah & 0 & $0,00 \%$ \\
\hline
\end{tabular}

Menurut tabel 6 dapat dikatakan bahwa tingkat attachment siswa SMP Teuku Umar Semarang Tahun Pelajaran 2019/2020 dengan frekuensi paling tinggi adalah 86 siswa yang memiliki persentase $47,25 \%$ dan termasuk kategori tinggi. Kemudian frekuensi paling tinggi kedua adalah 82 siswa yang memiliki persentase 45,06\% termasuk pada kategori sangat tinggi. Selanjutnya terdapat frekuensi sebanyak 13 siswa yang memiliki presentase $7,14 \%$ termasuk dalam kategori sedang lalu yang terakhir terdapat frekuensi sebanyak 1 siswa dengan persentase 0,55\% dan termasuk dalam kategori yang rendah. Untuk lebih mudahnya, hasil dari penelitian ini ketika dilihat melalui grafik sebagai berikut:

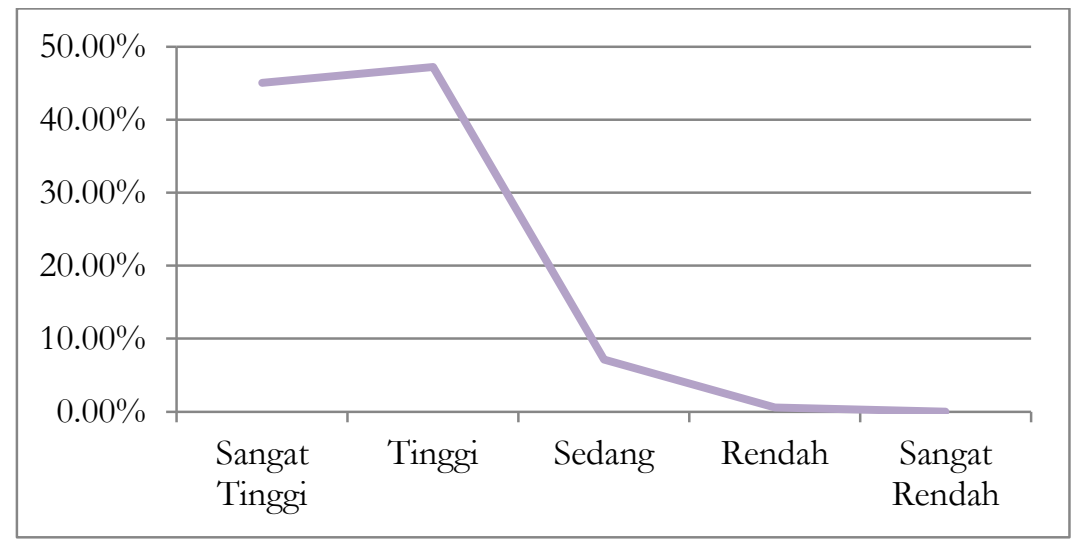

Gambar 3 Grafik Tingkat Attachment 
Berdasarkan grafik 3 dapat menunjukkan bahwa kecenderungan siswa SMP Teuku Umar Semarang Tahun Pelajaan 2019/2020 mempunyai tingkat attachment yang tinggi dengan frekuensi 86 responden dan memiliki persentase $47,25 \%$. Selanjutnya deskripsi data dari setiap indikator pada variabel attachment adalah secure attachment, avoidant attachment, ambivalent attachment yang dirangkum dalam tabel di bawah ini:

Tabel 7. Hasil Analisis Deskriptif per Indikator Attachment

\begin{tabular}{lccc}
\hline Indikator & $\mathbf{N}$ & $\mathbf{M}$ & SD \\
\hline Secure Attachment & 182 & 4,02 & 0,964 \\
Avoidant Attachment & 182 & 3,72 & 0,994 \\
Ambivalent attachment & 182 & 3,80 & 1,05 \\
\hline
\end{tabular}

Dari tabel 7 menunjukkan hasil analisis deskriptif per indikator yang pertama indikator secure attachment memiliki $(\mathrm{M}=4,02 ; \mathrm{SD}=0,964)$, avoidant attacbment sebanyak $(\mathrm{M}=3,72 ; \mathrm{SD}=0,994)$, dan yang terakhir yaitu ambivalent attachmnent sebanyak $(\mathrm{M}=3,80 ; \mathrm{SD}=1,05)$. Untuk lebih jelasnya dapat dilihat pada grafik di bawah ini:

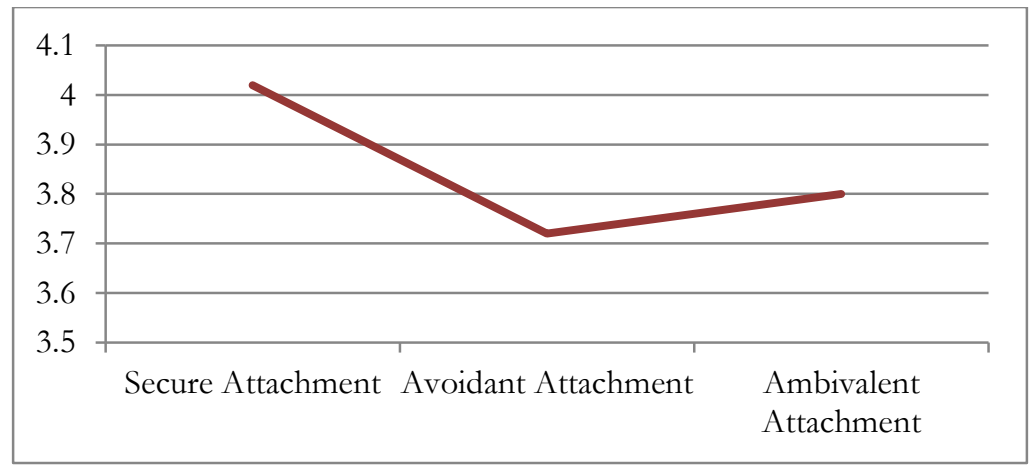

Gambar 4. Grafik Tingkat Attachment per Indikator

Selanjutnya diperoleh data dari attachment yang tertera pada tabel berikut:

Tabel 8. Distrbusi Responden Tingkat Penyesuaian Diri

\begin{tabular}{cclcc}
\hline No & Interval & \multicolumn{1}{c}{ Kategori } & F & Persentase \\
\hline 1. & $\mathrm{X} \geq 72$ & Sangat Tinggi & 7 & $3,85 \%$ \\
2. & $60 \leq \mathrm{X}<72$ & Tinggi & 108 & $59,34 \%$ \\
3. & $48 \leq \mathrm{X}<60$ & Sedang & 64 & $35,16 \%$ \\
4. & $36 \leq \mathrm{X}<48$ & Rendah & 3 & $1,65 \%$ \\
5. & $\mathrm{X}<36$ & Sangat Rendah & 0 & $0,00 \%$ \\
\hline
\end{tabular}

Menurut tabel 8 dapat dikatakan bahwa tingkat penyesuaian diri siswa SMP Teuku Umar Semarang Tahun Pelajaran 2019/2020 dengan frekuensi paling tinggi adalah 108 siswa yang memiliki persentase 69,34\% dan termasuk kategori tinggi. Kemudian frekuensi paling tinggi kedua adalah 64 siswa yang memiliki persentase 35,16\% termasuk pada kategori sedang. Selanjutnya terdapat frekuensi sebanyak 7 siswa yang memiliki persentase 3,85\% termasuk dalam kategori sangat tinggi lalu yang terakhir terdapat frekuensi sebanyak 3 siswa dengan persentase 1,65\% dan termasuk dalam kategori yang rendah. Untuk lebih mudahnya, hasil dari penelitian ini ketika dilihat melalui grafik berikut: 


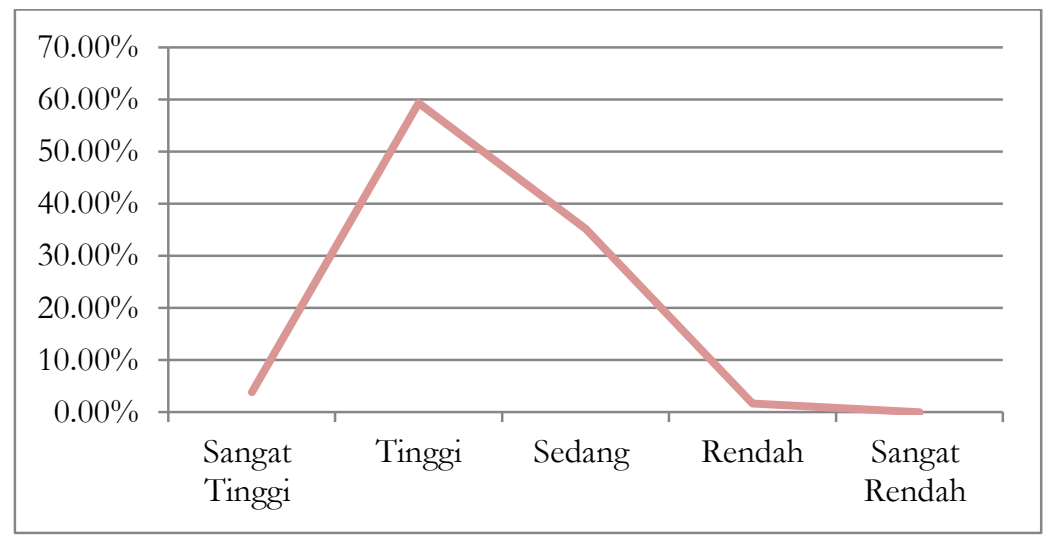

Gambar 5. Grafik Tingkat Penyesuaian Diri

Berdasarkan garifk 5 dapat menunjukkan bahwa kecenderungan siswa SMP Teuku Umar Semarang Tahun Pelajaran 2019/2020 mempunyai tingkat penyesuaian diri yang tinggi dengan frekuensi 108 responden dan memiliki persentase 59,34\%. Selanjutnya deskripsi data dari setiap indikator pada variabel penyesuaian diri dan dirangkum dalam tabel di bawah ini:

Tabel 9 Hasil Analisis Deskriptif per Indikator Penyesuaian Diri

\begin{tabular}{lccc}
\hline \multicolumn{1}{c}{ Indikator } & N & M & SD \\
\hline Peresepsi yang akurat terhadap realita & 182 & 3,54 & 1,301 \\
Kemampuan untuk mengatasi stress dan kecemasan & 182 & 3,27 & 1,280 \\
Self-image yang positif & 182 & 3,60 & 1,356 \\
Kemampuan untuk mengungkapkan perasaan & 182 & 2,57 & 1,137 \\
Hubungan interpersonal yang baik & 182 & 3,88 & 0,984 \\
\hline
\end{tabular}

Dari tabel 9 menunjukkan hasil analasis deskriptif per indikator yang pertama indikator hubungan interpersonal yang baik memiliki $(M=3,88 ; S D=0,984)$, self-image yang positif sebanyak $(\mathrm{M}=3,60 ; \mathrm{SD}=1,356)$; persepsi yang akurat terhadap realita memiliki $(\mathrm{M}=3,54$; $\mathrm{SD}=1,301)$; kemampuan untuk mengatasi stress dan kecemasan yaitu $(\mathrm{M}=3,27 ; \mathrm{SD}=, 280)$; dan yang terakhir indikator kemampuan untuk mengungkapkan perasaan sebanyak $(\mathrm{M}=2,57$; $\mathrm{SD}=1,137)$. Untuk lebih jelasnya dapat dilihat pada grafik di bawah ini:

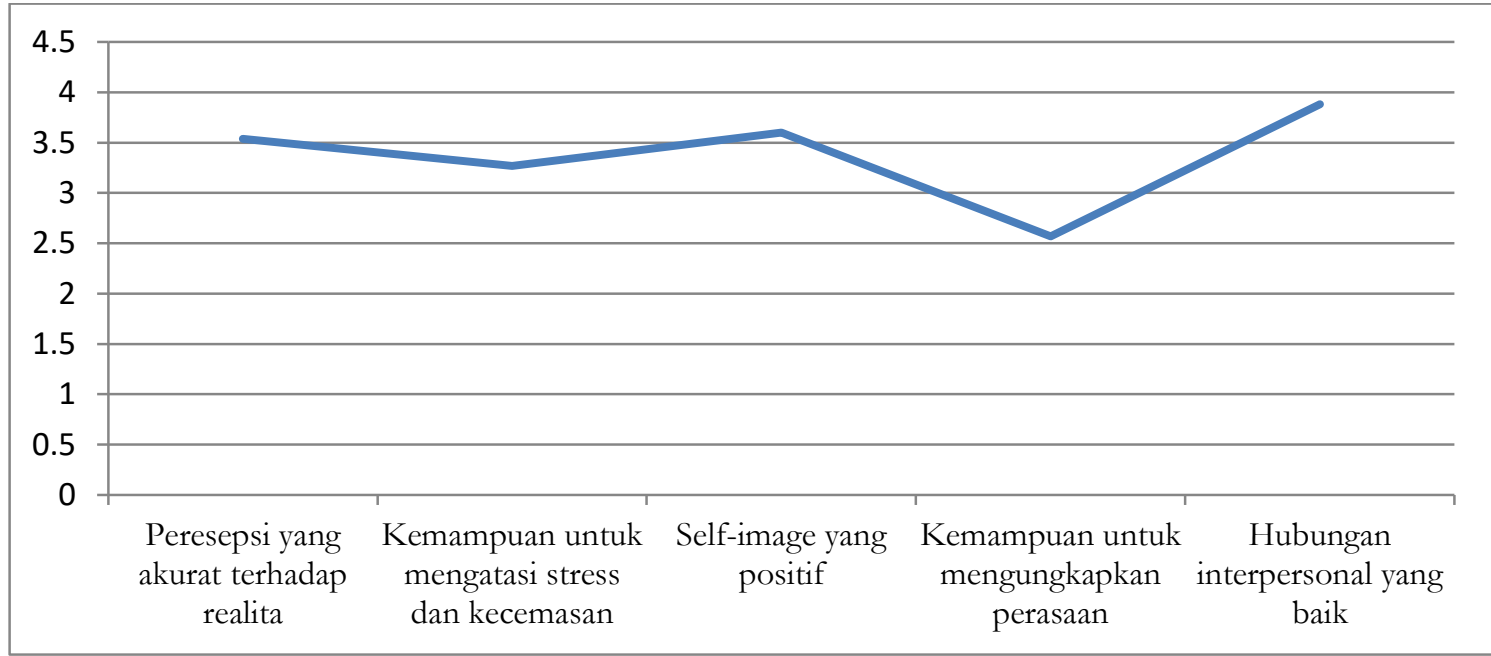

Gambar 6. Grafik Tingkat Penyesuaian Diri per Indikator 
Untuk mengetahui pengaruh attachment dan penyesuaian diri terhadap self-esteem siswa SMP Teuku Umar Semarang Tahun Pelajaran 2019/2020 menggunakan uji regresi ganda menggunakan SPSS 26.0. Namun terlebih dahulu dilakukan uji normalitas, uji linearitas, uji multikolinearitas, uji heteroskedastisitas. Kemudian uji normalitas data dalam penelitian ini memakai rumus one sample Kolmogorov-smirnov test.

Tabel 10. Hasil Uji Normalitas

\begin{tabular}{cc}
\hline $\mathbf{N}$ & Asymp. Sig. (2-tailed) \\
\hline 182 & 0,096 \\
\hline
\end{tabular}

Berdasarkan tabel 10 menunjukkan bahwa $(\mathrm{K}-\mathrm{S}=0,096)$ dengan kata lain signifikasi $>0,05$. Oleh karena itu, uji normalitas tersebut menunjukkan bahwa data pada penelitian ini berdistribusi normal selanjutnya dapat dihitung menggunakan uji regresi. Kemudian Hasil dari pengujian linearitas dapat dilihat pada tabel berikut ini:

Tabel 11. Hasil Uji Linearitas

\begin{tabular}{ccc}
\hline Variabel & Sig & Ket \\
\hline Self-Esteem * Attachment & 0,803 & Linear \\
Self-Esteem * Penyesuaian Diri & 0,413 & Linear \\
\hline
\end{tabular}

Dari tabel 11 dihitung menggunakan bantuan program SPSS 26.0 menunjukkan bahwa nilai p pada variabel self-esteem dengan attachment sebesar 0,803 kemudian variabel self-esteem dengan penyesuaian diri sebesar 0,413. Dengan demikian dapat disimpulkan bahwa variabel mempunyai hubungan yang linear dan penelitian tersebut memenuhi syarat untuk melakukan uji regresi. Kemudian uji multikolinearitas dapat dilihat pada tabel berikut:

Tabel 12. Hasil Uji Multikolinearitas

\begin{tabular}{lccc}
\hline \multicolumn{1}{c}{ Variabel } & Tolerance & VIF & Ket \\
\hline Attachment & 0,638 & 1,568 & Tidak Terjadi \\
Penyesuaian Diri & 0,638 & 1,568 & Tidak Terjadi \\
\hline
\end{tabular}

Dari tabel 12 menunjukkan bahwa nilai tolerance baik variabel X1 maupun variabel X2 memiliki tolerance sebanyak 0,638 dengan nilai VIF setiap variabel X1 dan variabel X2 sebanyak 1,568. Dengan hasil yang demikian menunjukkan bahwa variabel X1 dan variabel X2 atau dalam penelitian ini variabel attachment dan variabel penyesuaian diri tidak terjadi multikolinearitas, maka memenuhi syarat untuk dilakukannya uji regresi. Selanjutnya uji heteroskedastisitas dapat dilihat pada tabel berikut ini:

Tabel 13. Hasil Uji Heteroskedastisitas

\begin{tabular}{lll}
\hline Variabel & Sig & Ket \\
\hline Attachment & 0,267 & Tidak Terjadi \\
Penyesuaian Diri & 0,113 & Tidak Terjadi \\
\hline
\end{tabular}

Dari tabel 13 menunjukkan bahwa hubungan antara variabel Attachment yang sudah diberikan nilai residual,menghasilkan nilai signifikasi 0,267 kemudian variabel penyesuaian diri setelah ditambahkan nilai residual juga mengasilkan 0,113. Hasil yang terdapat dalam tabel di atas 
memberkan gambaran bahwa tidak terjadi gejala heteroskedastisitas, oleh karena itu memenuhi syarat untuk melanjutkan pada uji regresi. Selanjutnya uji regresi ganda yang dirangkum pada tabel:

Tabel 14. hasil Uji Regresi Ganda

\begin{tabular}{lcccccc}
\hline \multicolumn{1}{c}{ Prediktor } & $\mathbf{R}$ & $\mathbf{R}^{2}$ & $\mathbf{F}$ & $\boldsymbol{\beta}$ & $\mathbf{t}$ & Sig \\
\hline Attachment & - & - & - & 0,589 & 10,01 & 0,000 \\
Penyesuaian Diri & - & - & - & 0,265 & 4,50 & 0,000 \\
Attachment dan Penyesuaian & 0,778 & 0,605 & 137,096 & - & - & 0,000 \\
Diri & & & & & &
\end{tabular}

Hasil uji regresi ganda ditabel 14 adalah $(\beta=0,589 ; \mathrm{t}=10,01 ; \mathrm{p}=0,000)$, kemudian untuk memperoleh thitung dapat dilakukan dengan cara thitung 10,012 $>\mathrm{t}$ tabel $=1,651$ dan nilai sig $=$ $0,000<0,05$, sehingga memberikan pembuktian bahwa hipotesis untuk yang pertama dapat diterima atau dapat diartikan bahwa semakin tinggi attachment siswa maka akan semakin tinggi pula tingkat self-esteem siswa SMP Teuku Umar Semarang Tahun Pelajaran 2019/2020 dan sebaliknya. Juga didapati hasil $\beta=0,589$ sehingga nilai koefisien regresi juga bernilai positif maka dapat disimpulkan attachment memiliki pengaruh yang kuat dan positif.

Hasil dari regresi ganda adalah $(\beta=0,265 ; \mathrm{t}=4,504 ; \mathrm{p}=0,000)$, kemudian untuk memperoleh $\mathrm{t}$ hitung dapat dilakukan dengan cara $\mathrm{t}$ hitung 4,504 $>\mathrm{t}$ tabel $=1,651$ dan nilai sig $=0,000<0,05$. Sehingga memberikan pembuktian bahwa hipotesis untuk yang kedua dapat diterima atau dapt diartikan bahwa semakin tinggi penyesuaian diri siswa maka akan semakin tinggi pula tingkat selfesteem siswa SMP Teuku Umar Semarang Tahun Pelajaran Tahun Pelajaran 2019/2020 dan sebaliknya. Juga didapati hasil $\beta=0,265$ sehingga nilai koefisien regresi juga bernilai positif maka dapat disimpulkan penyesuaian diri memiliki pengaruh yang kuat dan positif.

Hasil uji regresi ganda pada tabel 14 menunjukkan bahwa attachment dan penyesuaian diri dengan self-esteem terbukti mempunyai pengaruh yang positif dan signifikan $\left(R=0,778 ; R^{2}=0,605\right.$; $\mathrm{F}=137,096 ; \mathrm{p}=0,000)$. Berdasarkan hasil tersebut dapat memberikan penjelasan bahwa hipotesis yang terakhir dinyatakan diterima, selain itu attachment dan penyesuaian diri secara serentak dapat mempengaruhi self-esteem siswa. Nilai koefisien korelasi berada pada $\mathrm{R}=0,778$, artinya adalah pengaruh attachment dan penyesuaian diri terhadap self-esteem siswa berada pada tingkat yang kuat. Hasil uji determinan yaitu $\mathrm{R}^{2}=0,605$ dapat diartikan bahwa pengaruh attachment dan penyesuaian diri terhadap self-esteem sebesar 60,5\% perhitungan tersebut didapatkan dari $\left(\mathrm{R}^{2}=0,605 \times 100 \%=\right.$ 60,5\%). Kemudian ada lebihnya yaitu 39,5\% kemungkinan ada pada variabel lain namun tidak diteliti pada penelitian ini. Dengan kata lain semakin tinggi attachment dan penyesuaian diri siswa, maka semakin tinggi juga tingkat self-esteem siswa.

Menurut Febrina et al., (2017) mengatakan bahwa self-esteem merupakan tindakan seseorang untuk menilai secara sadar terhadap diri sendiri. Adapun pendapat Pahlevi, Sugiharto \& Jafar (2017) bahwa seseorang yang memiliki self-esteem yang cenderung rendah biasanya sedikit mempunyai kemauan dalam mengolah mood yang negatif dan cenderung regulasi dirinya rendah. Penelitian ini memiliki tujuan untuk mengetahui pengaruh attachment dan penyesuaian diri terhadap self-esteem siswa.

Hasil penelitian menunjukkan bahwa attachment dan penyesuaian diri memiliki pengaruh atau memiliki kontribusi yang positif dan kuat dimana ada 60,5\% terhadap self-esteem siswa. Dengan begitu 
masih ada sisa sebesar 39,5\% diprediksi ada pada variabel yang tidak diteliti. Maka dapat diartikan bahwa semakin tinggi attachment dan penyesuaian diri siswa, maka semakin tinggi juga tingkat selfesteem siswa. Menurut Afari, Ward \& Khine (2012) menjelaskan bahwa self-esteem pada seseorang merupakan salah satu faktor utama dalam konsep diri dan dianggap sebagai penentu penting dalam perilaku manusia karena self-esteem sudah diuji dalam berbagai berbagai konteks pendidikan, sosiologis dan psikologis.

Pada dasarnya self-esteem pada diri seseorang adalah bersifat tidak tetap, keadaan self-esteem pada seseorang tergantung pada keberhasilan dan pengharapan seseorang. Karena self-esteem pada diri seseorang memiliki peran penting pada diri salah satunya adalah memiliki rasa menghargai untuk diri sendiri bahkan untuk orang lain, agar dapat mencapai tugas perkembangannya dengan optimal. Penelitian yang dilakukan oleh Knight, Sibc, Gantt, Carapezza \& Macon (2018) menjelaskan bahwa teori attachment menurut Bowlby dan Ainsworth adalah hubungan atau bagaimana seseorang menjalin ikatan dengan orang lain. Sesuai dengan hasil penelitian yang telah dilaksanakan menunjukkan bahwa adanya pengaruh yang positif dan signifikan dari variabel attachment terhadap self-esteem. Selanjutnya untuk variabel-variabel tersebut sudah dijelaskan bahwa bernilai positif sehingga attachment memiliki kontribusi yang positif terhadap selfesteem siswa. Dapat artikan bahwa semakin tinggi attachment pada setiap siswa di sekolah maka akan semakin tinggi juga self-esteem siswa. Menurut Tedra (2017) mengatakan bahwa interaksi secara psikologis itu merupakan sebuah kelekatan atau attachment. Santrock (2002) mengemukakan bahwa attachment berlandaskan pada suatu hubungan dua orang yang memiliki ikatan kuat pada setiap masing-masing individu dan berbagai hal dilakukan bersama demi keberlangsungan hubungan tersebut. Oleh karena itu attachment pada setiap orang beda-beda karena cara orang tua memberikan pola asuh pun berbeda-beda yang dapat membentuk kelekatan pada anak dengan orang tua dan kelekatan anak dengan orang lain. Seseorang yang memiliki kelekatan yang baik maka cenderung akan memiliki tingkat percaya diri yang tinggi dan memiliki kemampuan dalam menghargai diri sendiri (self-esteem). Penemuan sejenis menjelaskan tentang attachment (kelekatan) dengan orang tua mempunyai beberapa pengaruh pada faktor-faktor yang dapat didalami dari setiap anak diantaranya adalah regulasi emosi, harga diri (self-esteem), konformitas dan resiliensi yang nantinya akan diberdayagunakan untuk membangun attachment anak dengan orang tua agar faktor dari dalam diri anak diantaranya regulasi emosi, self-esteem, konformitas dan resilisiensi akan dibentuk dan dimanfaatkan secara optimal (Muarifah, Fauziah \& Saputra, 2020).

Didukung juga oleh penelitian yang dilakukan oleh Psouni \& Apetroaia (2014) yang hasil penelitiannya lebih menekankan pada interaksi anak dengan ayah dan ibunya sebelum si anak ada pada fase sekolah. Kemudian kelekatan (attachment) yang kuat dengan ibu tidak selalu melibatkan kelekatannya dengan ayah. Sehingga apabila berbicara mengenai kenyamanan anak, dapat dikatakan bahwa disarankan fokus pertama yang anak harus dapatkan adalah attachment yang aman dengan ibu, sedangkan fokus kedua adalah attachment dengan ayah. Kedua peran ayah dan ibu dalam tumbuh kembang anak memang penting dan memiliki peran yang berbeda-beda dan sama penting oleh karena itu untuk membentuk suatu hubungan yang saling memiliki keterkaitan dan saling mempertahankan perlu adanya kerjasama. Seseorang memiliki attachment yang berbeda-beda tergantung pola seperti apa yang didapatkan dari keluarga atau orang tua yang merawat sedari kecil. Karena pola yang tertanam sejak dini akan mempengaruhi sikap dan sifat seseorang ketika sudah dewasa. Hasil penelitian selanjutnya mengenai self-esteem secara jelas mengungkapkan bahwa telah 
dikonfirmasi apabila seseorang yang memiliki self-esteem yang rendah cenderung memiliki kecemasan yang lebih tinggi. Hal tersebut dikarenakan bahwa selfesteem adalah sebuah evaluasi diri pada seseorang, dengan memiliki self-esteem yang rendah bukan hanya mengkhawatirkan dirinya bersikap kepada orang lain tetapi juga mengkhawatirkan bagaimana orang lain memandang dirinya. Self-esteem juga sering dikaitkan dengan cara menilai seseorang berdasarkan pengetahuan yang dimiliki kemudian diukur dengan seberapa efektivitasnya dalam menjalankan kehidupan yang saling berinteraksi antara satu dengan yang lainnya. Seseorang akan merasa memiliki self-esteem yang rendah ketika seseorang menunjukkan perilaku yang memungkinkan perilaku tersebut mendapat penolakan dari orang yang ada disekitarnya (Ma, Liang, Zeng, Jiang \& Liu, 2014). Tinggi rendahnya self-esteem pada diri seseorang berbeda-beda, tergantung dari sudut pandang mana memandanganya. Ketika melihat dari sisi attachment yang mempengaruhi terbentuknya selfesteem maka dapat dilihat bahwa seseorang dibentuk oleh orang tua, bagaimana orang tua memperlakukan. Dari hal tersebut akan diketahui self-esteem pada diri seseorang, baik buruknya seseorang dalam menilai dirinya sendiri dan menginterpretasikan penilaian orang lain terhadap dirinya.

Sebagaimana dalam penelitian ini yang sudah dilakukan yaitu penelitian ini menunjukkan,bahwa ada 60,2\% self-esteem mendapat pengaruh dari attachment dengan secure attachment sebagai indikator yang paling tinggi. Dapat diketahui bahwa seseorang yang memiliki secure attachment biasanya kurang membutuhkan persetujuan orang lain karena cukup percaya diri dengan pilihannya sendiri, relatif mudah untuk memulai dan mengembangkan hubungannya dengan orang lain. Disamping itu, orang dengan secure attachment dapat mengatur diri sendiri untuk mandiri, menganggap dirinya layak untuk dicintai oleh orang disekitarnya, dan percaya bahwa oraang lain dapat diandalkan (Tagay \& Karatas, 2012). Seseorang yang mempunyai self-esteem yang tinggi dapat diketahu apabila seseorang tersebut dapat meningkatkan probabilitas keberhasilan, dapat mengurangi efek kegagalan sehingga diharapkan dapat mengembangkan aktualisasi dirinya dengan optimal (Mulawarman, Nugroho, Susilawati, Afriwilda \& Kunwijaya, 2019).

Oleh karena itu sehubungan dengan hal tersebut guru bimbingan dan konseling di sekolah memiliki peran yang penting dalam pengembangan attachment dan self-esteem siswa. Serangkaian dengan tugas pokok dan fungsi dari guru bimbingan dan konseling yang mengupayakan perkembangan siswa secara optimal sehingga perlu untuk memberikan layanan yang memungkinkan untuk meningkatkan attachment dan selfesteem siswa yaitu konseling individu dan bimbingan kelompok. Muncul dugaan bahwa self-esteem yang rendah itu karena pada dasarnya selfesteem terbentuk dengan adanya interaksi seseorang dengan lingkungan. Karena setiap orang memiliki pola interaksi yang berbeda dengan lingkungan. Ada yang berhasil menyesuaikan diri di lingkungannya dengan baik, sebaliknya ada yang kurang mampu menyesuaikan diri di lingkungaan dengan baik.

Penyesuaian diri disini memiliki makna bahwa upaya seseorang untuk merubah diri agar sesuai dengan lingkungan atau merubah lingkungan agar sesuai dengan dirinya sendiri (Badian \& Soedarmadji, 2018). Dari hasil penelitian yang sudah dilakukan bahwa attachment dan penyesuaian diri memiliki kontribusi yang positif terhadap self-esteem. Maka dari itu peran guru Bimbingan dan Konseling di sekolah sangat diperlukan untuk menjembatani siswa dalam mengembangkan attachment dan membantu siswa dalam melakukan penyesuaian diri yang baik agar tercapainya selfesteem yang baik juga pada diri siswa. 
Didukung penelitian yang dilakukan oleh Maranata, Wibowo \& Sugiharto (2019) mengatakan bahwa penyesuaian diri merupakan hal yang akan dirasakan oleh setiap orang guna mencapai peran dalam bermasyarakat dan dalam hal ini perlu melibatkan perilaku dan respon mental sehingga bukan berarti tidak sesuai dengan norma yang berlaku. Ketika lingkungan yang ditinggali itu menyediakan hal-hal yang menyenangkan maka dapat meningkatkan self-esteem siswa dan ketika lingkungan menyediakan hal-hal yang tidak menyenangkan maka dapat menurunkan self-esteem seseorang. Oleh karena itu, apabila seseorang kurang mampu melakukan penyesuaian diri dengan baik, maka akan berpengaruh terhadap rendahnya self-esteem pada diri seseorang diantaranya adalah akan menghalangi seseorang dalam meraih keinginan, hilangnya kepercayaan diri dan kurangnya rasa untuk menghargai diri sendiri.

Berdasarkan penelitian yang dilakukan oleh Kustanti (2017) menjelaskan bahwa terdapat hubungan antara kelakatan dan penyesuaian sosial dengan harga diri. Dimana penelitian tersebut cukup mendukung dalam penelitian yang sudah dilaksanakan oleh peneliti. Hanya saja perbedaan antara penelitian tersebut dengan penelitian yang dilakukan oleh penulis adalah pada penelitian tersebut dilakukan untuk mencari hubungan, namun penelitian yang dilakukan oleh penulis mencari pengaruh dari keterhubungan ketiga variabel dalam penelitian. Dari hasil penelitian yang sudah dilakukan bahwa attachment dan penyesuaian diri memiliki kontribusi yang positif terhadap self-esteem. Maka dari itu peran guru Bimbingan dan Konseling di sekolah sangat diperlukan untuk menjembatani siswa dalam mengembangkan attachment dan membantu siswa dalam melakukan penyesuaian diri yang baik agar tercapainya self-esteem yang baik juga pada diri siswa. Berbagai cara dapat guru bimbingan dan konsling lakukan dalam mengupayakan hal tersebut dapat tercapai salah satunya adalah dengan diberikannya layanan baik layanan individu, layanan kelompok ataupun layanan klasikal. Namun di sekolah guru bimbingan konseling juga tidak bisa jalan sendiri, melainkan memerlukan bantuan dari berbagai unsur yang ada di sekolah. Perlu adanya kerjasama yang baik dan kompak untuk setiap pihak di sekolah agar dapat mendukung terselenggaranya program layanan bimbingan dan konseling di sekolah demi teratasinya permasalahan siswa yang mengganggu serta tercapainya tugas perkembangan siswa dengan optimal.

Sesuai dengan hasil,penelitian yang telah dilaksanakan menunjukkan bahwa adanya pengaruh yang positif dan signifikan dari variabel penyesuaian diri terhadap self-esteem. Selanjutnya untuk variabel-variabel tersebut sudah dijelaskan bahwa bernilai positif sehingga penyesuaian diri memiliki kontribusi yang positif terhadap self-esteem siswa. Dapat artikan bahwa semakin tinggi penyesuaian diri pada setiap siswa di sekolah maka akan semakin tinggi juga self-esteem siswa. Menurut Costa (2018) menyampaikan bahwa penyesuaian diri merupakan proses perubahan dalam diri individu terhadap lingkungannya dan berupaya untuk menciptakan lingkungan yang seimbang dan harmonis. Perubahan tersebut dapat membangkitkan perasaan yang kurang bahagia karena seseorang dituntut untuk melakukan suatu hal yang baru pada diri dan lingkungannya. Oleh karena itu karena seseorang yang berada pada fase penyesuaian diri dengan lingkungannya belum tentu dapat berjalan lancar atau terdapat beberapa masalah di dalamnya. Dari hal tersebut akan menyebabkan rendahnya self-esteem pada diri seseorang diantaranya karena sulit dalam menyesuaikan diri dengan lingkungan yang ada disekitarmya. Apabila seseorang yang memiliki penyesuaian diri yang baik maka dapat menerima dirinya sendiri dengan baik, dapat menyesuaikan diri dengan tuntutan lingkungan dan kebutuhan untuk diterima dan diakui oleh lingkungan sekitarnya, dapat mengatasi masalah atau keadaan yang 
sulit, mampu untuk memenuhi kebutuhannya. Selain itu ada kriteria lain untuk dasar penyesuaian diri yang baik diantaranya adalah pengetahuan yang diperoleh selama berproses sehingga membetuk sebuah wawasan, memiliki kemampuan dalam menerima diri sendiri dengan baik, mampu mengontrol setiap tindakan sehingga mampu mengembangkan diri dengan baik, dan mampu menjalin hubungan interpersonal yang baik (Arifin, Dardiri \& Handayani. 2016). Seringkali seseorang yang memiliki penyesuaian diri itu memiliki fase peralihan dari satu tempat ke tempat lainnya, peralihan dari satu keadaan ke keadaan lainnya. Dalam keadaan tersebut atau sering disebut sebagai penyesuaian diri dan tidak semua orang dapat melakukannya dengan baik.

Penelitian ini memiliki hasil yang sesuai seperti penelitian yang sudah dilakukan oleh Margarethabertiutami (2016) yang menunjukkan bahwa terdapat pengaruh antara penyesuaian diri terhadap self-esteem siswa. Siswa berusaha untuk menyesuaikan diri dengan ritme belajar di sekolah baru dengan belajar lebih keras merupakan upaya untuk meraih nilai yang tinggi agar dapat naik kelas. Hal tersebut berawal dari perolehan nilai yang sebelumnya banyak siswa yang merasa bahwa nilai yang sudah diperoleh itu masih jauh dibawah targetnya sehingga hal tersebut menjadi acuan untuk terus menjaga prestasi yang didapatkan. Karena dengan prestasi yang didapatkan itu dapat membuat siswa lebih mernghargai dirinya sendiri dan membuat orang lain untuk menghargai prestasi yang sudah diraihnya. Hal yang berbeda dengan penelitian yang dilakukan oleh Margarethabertiutami (2016) adalah jumlah variabel yang diteliti. Dari penelitian yang sudah dilakukan oleh Reber (2012) sejalan dengan penelitian ini, yang ditunjukkan bahwa adanya pengaruh penyesuaian diri terhadap self-esteem ditandai dengan adanya indikator yang paling rendah adalah keberartian dan indikator yang paling tinggi adalah kekuatan. Hal tersebut menunjukkan bahwa seseorang yang memiliki self-esteem yang tinggi, baik seseorang ada dilingkungan yang sudah lama ditinggai atau lingkungan yang baru ditinggali dengan suasana yang baru maka dapat menyesuaikan diri dengan baik. Untuk mengatasi semua kemungkinan terburuk dari kurangnya kemampuan seseorang dalam melakukan penyesuaian diri maka guru bimbingan dan konseling di sekolah sangat penting perannya. Karena guru bimbingan dan konseling di sekolah dapat memberikan layanan yang sesuai dengan kebutuhan siswa seperti bimbingan kelompok atau konseling kelompok untuk mengetahui penyesuaian diri yang terjadi pada siswa dan untuk meningkatkan self-esteem agar siswa dapat mengembangkan diri dengan optimal.

Ada berbagai hal yang terjadi dan menjadi keterbatasan dalam penelitian ini, diantaranya adalah Tempat yang dilakukan untuk penelitian ini hanya mencakup di satu sekolah saja di Semarang dan tidak semua kelas dijadikan sampel penelitian. Ketika melaksanakan penelitian ada dimasa pandemi covid-19 sehingga banyak sekali peralihan situasi, keadaan dari berbagai sektor. Sehingga berbagai cara diusahakan agar penelitian tetap berjalan, sehingga peneliti menyebarkan instrumen penelitian menggunakan google form dengan saran dari dosen pembimbing karena peneliti tidak bisa menyebarkan langsung di sekolah.

\section{Kesimpulan}

Kesimpulan penelitian ini yaitu: 1). Terdapat pengaruh yang yang positif dan signifikan attachment terhadap self-esteem siswa SMP Teuku Umar Semarang Tahun Pelajaran 2019/2020. Dengan kata lain semakin tinggi attachment pada siswa maka akan semakin tinggi juga self-esteem siswa SMP Teuku Umar Semarang Tahun Pelajaran 2019/2020; 2) Terdapat pengaruh yang positif dan signifikan penyesuaian diri terhadap self-esteem siswa SMP Teuku Umar Semarang Tahun 
Pelajaran 2019/2020. Dimana semakin tinggi penyesuaian diri maka akan semakin tinggi juga selfesteem siswa SMP Teuku Umar Semarang Tahun Pelajaran 2019/2020; 3) Terdapat pengaruh yang positif dan signifikan attachment dan penyesuaian diri terhadap self-esteem siswa SMP Teuku Umar Semarang. Dapat diartikan bahwa semakin tinggi attachment dan penyesuaian diri pada siswa maka akan semakin tinggi juga self-esteem siswa SMP Teuku Umar Semarang Tahun Pelajaran $2019 / 2020$

\section{Referensi}

Afari, E., Ward, G., Khine, M. S. (2012). Global Self-Esteem and Self-Efficacy Correlates: Relation of Academic Achievement and Self-Esteem among Emirates Students. International Education Studies 5(2)

Aini, N., Sugiharto, DYP., \& Sutoyo, A. (2014) Pengembangan Model Bimbingan Kelompok dengan Teknik Sosiodrama Untuk Meningkatkan Penyesuaian Diri Siswa. Jurnal Bimbingan dan Konseling 3(2) 2014

Akila (2017) Pengaruh Intensif dan Pengawasan Terhadap Produktivitas Kerja Karyawan Pada CV. Vassel Palembang. Jurnal Ecoment Global 02(02) Agustus 2017.

Alfaiz, A., \& Yandri, H. (2015). Self concept and self efficacy as a ground points in a social activities (an analysis of psychology perspective: a social cognitive theory). Jurnal Pelangi, 7(2).

Astuti, K \& Trisakti. (2014). Hubungan Antara Harga Diri dan Persepsi Pola Asuh Orang Tua yang Authoritatif dengan Sikap Remaja Terhadap Penyalahgunaan Narkoba. Jurnal Ilmiah Guru " COPE” (2)

Ayuwardani, R. P., \& Isroah, I. (2018). Pengaruh Informasi Keuangan Dan Non Keuangan Terhadap Underpricing Harga Saham Pada Perusahaan Yang Melakukan Initial Public Offering (Studi Empiris Perusahaan Go Public Yang Terdaftar Di Bursa Efek Indonesia Tahun 2011-2015). Nominal, Barometer Riset Akuntansi Dan Manajemen, 7(1).

Bhakti, C. P., Safitri, N. E., \& Dewi, A. C (2017) Strategi Layanan Bimbingan dan Konseling Untuk Mengurangi Perundungan Siber di Kalangan Remaja. Jurnal Psikoedukasi dan Konseling 2(2) Desember 2018.

Bowlby, John. 1982. Attachment and Loss. Basic Books

Cenceng (2015). Perilaku Kelekatan Pada Anak Usia Dini (Perspektif John Bowlby). Lentera, 09(01) Desmber 2015.

Costa, A. D., Hanurawan, F., Atmoko, A., \& Hitipeuw, I. (2018). The Impact Of Self-Adjusment On Academic Achievement Of The Students. ISLLAC: Journal of Intensive Studies on Language, Literature, Art, and Culture 2(1), 2018

Devi, Y. R., \& Fourianalistyawati, E. (2018). Hubungan Antara Self-Esteem Dengan penyesuaian Diri Sebagai Peran Ibu Rumah Tangga Pada Ibu Berhenti Bekerja Di Jakarta. Jurnal Psibemetika 11(1), 9-20

Febrina, D. T., Suharso, P. L., \& Saleh, A. Y. (2018). Self-Esteem Remaja Awal: Temuan Baseline Dari Rencana Program Self-Instructional Training Kompetensi Diri. Jurnal Psikologi Insight, 2(1), 43-56. 
Husni, M. A., \& Purwaningsih, I. E. (2017). Identitas Diri Ditinjau Dari Kelekatan Remaja Pada Orang Tua Di Smkn 4 Yogyakarta. Jurnal Spirits, 4(1), 43.

Imani Khan, R. (2012). Perilaku Asertif, Harga Diri dan Kecenderungan Depresi. Persona:Jurnal Psikologi Indonesia, 1(2), 143-154.

Izzah, I. (2017). Peranan Gaya Kelekatan Kepada Orangtua Dengan Harga Diri Pada Remaja. Jurnal Sosiologi Reflektif, 11(2), 125.

Knight, A. M., Sibc, G. A., Gantt, A. C.,Carapezza. K. M., \& Macon, K. P. (2018). The Impact of Brief God Attachment Workshop Attandance on God Attachment. Virginia Counselors Journal 36, 2018

Kurland, R. M., \& Siegel, H. I. (2013). Attachment and Student Success During the Transition to College. Nacada Journal 33(2)

Kustanti, E. R. (2017). Kelekatan, Harga Diri dan Penyesuaian Sosial Pada Korban Perundungan. Jurnal Psikologi 16(2) 2017, 113-121

Lestari, A., I \& Widiandhono, H. (2019) Pengauh Motivasi, Kompensasi dan Kepuasan Kerja Terhadap Kinerja Karyawan Pada pt bpr Yudha Kencana Banjarnegara. Jurnal Manajemen dan Bisnis Media Ekonomi 19(01)

Margarethabertiutami (2016). Hubungan Antara Harga Diri Dan Penyesuaian Diri Siswi Kelas X SMA Tarakanita 1. Jurnal Psiko-Edukasi, 14(1), 68-76.

Mahmudi, M., \& Suroso (2014). Efikiasi Diri, Dukungan Sosial dan Penyesuaian Diri Dalam Belajar. Pesona, Jurnal Psikologi Indonesia 3(2), 183-194

Maulida, S., Mashabi, N. A., \& Hasanah, U. (2017). Hubungan Kelekatan Orang Tua Dengan Kemandirian Remaja. JKKP (Jurnal Kesejabteraan Keluarga Dan Pendidikan), 4(1), 1.

Mardapi, Djemari. (2008). Teknik Penyusunan Instrumen Tes dan Non Tes. Yogyakarta: Mitra Cendekia

Muarifah, A., Fauziah, M., \& Saputra, W. N. E. (2020). Pengaruh Parent-Child Attachment Terhadap Regulasi Emosi, Harga Diri, Konformitas dan Resiliensi Siswa. Jurnal Bimbingan dan Konseling 5(2), 2020, 63-71

Mubarok, A. F. (2012). Penyesuaian Diri Para Pendatang Di Lingkungan Baru. Journal of Social and Industrial Psychology 1(1)

Mulawarman., Nugroho, I. S., Susilawati., Kunwijaya, I., (2019). Enhancing Self-Esteem and Optimism Based On Classroom Guidance On Undergraduate Counseling Student In Indonesia. European Journal of Education Studies 6(5)

Muslimah, A. I., \& Wahdah, N. (2013). Hubungan Antara Attachment dan Self-Esteem dengan Need For Achievement pada Siswa Madrasah Aliyah Negeri 8 Cakung Jakarta Timur. Journal Soul 06(01) Maret 2013.

Nora, M. O. (2015). Pengaruh Kelekatan Dan Harga Diri terhadap Kemampuan Bersosialisasi Anak. Pendidikan Usia Dini, 9(2), 379-338.

Nurdin, Ali. (2018). Motivasi Kerja dan Lingkungan Belajar Dalam Upaya Peningkatan Proses Pembelajaran. Jurnal Tarbiyah 25(2)

Nurhayati, D. \& Sunardi. (2011). Hubungan antara Gaya Kelekatan (Attachment) dengan Konsep Diri pada Pecandu Narkoba di Rumah Cemara Bandung Tahun 2011. Jassi, 10(1), 29-41. 
Pahlevi, R., Sugiharto, D.Y. P., \& Jafar, M. (2017). Prediksi Self-Esteem, Social Support dan Religiusitas terhadap Resiliensi. Jurnal Bimbingan dan Konseling 6(1)

Permatasari, R. A., \& Savira, S. I., (2018). Hubungan Antara Self-Esteem dengan Penyesuaian Diri Pada Mahasiswa Psikologi Angkatan 2017 Universitas Negeri Surabaya. Character : Jurnal Penelitian Psikologi, 05(02).

Prastati, T., Sugiyo \& Saraswati, S. (2013). Faktor-Faktor yang Mempengaruhi Rendahnya Minat Siswa Memanfaatkan Layanan Konseling Perorangan. Indonesian Journal of Guidance and Counseling: Theory and Application.

Prasetyaningrum, S., \& Rahma, F. O. (2017). Kepribadian Terhadap Gaya Kelekatan Dalam Hubungan Persahabatan. Psympatbic: Jurnal Ilmiah Psikologi, 2(2), 153-168.

Priyono, L. D., Anni, C. T., \& Sugiyo. (2018) Pengaruh Kondisi Keluarga dan Self-Acceptance Terhadap Kepercyaan Diri Remaja. Indonesian Journal of Guidance and Counseling: Theory and Application 7(1)

Psouni, E., \& Apetroaia, A. (2014). Measuring Scripted Attachment-Related Knowledge in Middle Childhood: the Secure Base Acript Test. Attachment \& Human Development 16(1)

Puteri, M., \& Wangid, M. N. (2018). Hubungan Antara Kelekatan Dengan Interaksi Sosial Pada Siswa. Psikopedagogia Jurnal Bimbingan Dan Konseling, 6(2), 84.

Putra, Cita Bakti U. (2012) Kecerdasan Sosial Siswa Kelas Akselerasi. Educational Psychology Journal 1 (1) (2012).

Purnamasari, I., Suharso \& Sunawan. Kontribusi Empati dan Dukungan Sosial Teman Sebaya Terhadap Perilaku Prososial di SMP. Indonesiaon Journal of Guidance and Counseling: Theory and Application 7(2)

Purtomo, Tjahjo. 2014. Analisis Kualitas Pada Produksi Labelstock Kertas HVS d PT "X". Jurnal Teknik Industri heuristic, 11(01) April 2014.

Refnadi, R. (2018). Konsep Self-Esteem Serta Implikasinya Pada Siswa. Jurnal Educatio: Jurnal Pendidikan Indonesia, 4(1), 16.

Rilfani, Y. M (2017). Skripsi. Hubungan Pola Asuh Orang Tua dengan Penyesuaian Diri Peserta Didik di SMP Negeri 7 Padang.

Sugiyono. (2017). Metode Penelitian Pendidikan: Pendekatan Kuantitatif, Kualitatif dan R\&D. Bandung: CV Alfabeta

Sugiyono. (2016). Statistik Untuk Penelitian. Bandung: CV Alfabeta

Srisayekti, W., \& Setiady, D. A. (2015). Harga-diri (Self-esteem) Terancam dan Perilaku Menghindar. Jurnal Psikologi, 42(2), 141.

Syarifa, M., \& Indrawati, E. (2017). Hubungan Antara Kelekatan Aman Terhadap Ibu Dan Penyesuaian Diri Pada Mahasiswa Tahun Pertama Fakultas Psikologi Universitas Diponegoro. Empati, 6(1), 276-280.

Sugiharto \& Anggraeny. S. N., (2018). Mengukur Kualitas Akuntan Publik Menurut Pengguna Jasa Akuntan Publik. Jurnal Monex 07(01) 2018.

Sunawan, Andromeda, Muslikah, Reni P. W. A. S., \& Trimurtini. (2018). Pedoman Penulisan Skripsi. Semarang : FIP UNNES

Tagay, O., \& Karatas, Z. (2012). An Investigation of Attachment Styles of College Students. Procedia Social and Behavioral Sciences 47 (2012) 746-750. 
Tedra, L. B. (2017). Gaya Kelekatan Remaja dan Orang Tua Pada Siswa SMP Negeri 1 Nguter Kabupaten Sukoharjo. Indonesian Journal of Guidance and Counseling: Theory and Aplication 6(1) 2017.

Windaniati. (2015). Meningkatkan Kemampuan Penyesuaian Diri Siswa Melalui Teknik Cognitif Restructuring Pada Kelas X TKR 1 SMK Negeri 7 Semarang. Jurnal Penelitian Pendidikan 32(1) 2015.

Yusup, Febrianawati (2018). Uji Validitas dan Reliabilitas Instrumen Penelitian Kuantitatif. Jurnal Tarbiyah: Jurnal Ilmiah Kependidikan 07(01) Januari-Juni 2018 (17-23). http://jurnal.uinantasari.ac.id/index.php/jtij/article/download/2100/1544 